Серія: Педагогічні науки. - Вип.3. - Бердянськ : БДПУ, 2019. - 453 с.

ПОЧАТКОВА ОСВІТА

УДК 373.3.091.21:616.89-008.435

DOI 10.31494/2412-9208-2019-1-3-58-71

\title{
DEVELOPING LOGOCOMPETENCES OF PRIMARY SCHOOL TEACHER WITHIN THE LIMITS OF THE PROFESSIONAL STANDARDS
}

\author{
РОЗРОБЛЕННЯ ЛОГОКОМПЕТЕНТОСТЕЙ УЧИТЕЛІВ \\ ПОЧАТОВИХ КЛАСІВ У МЕЖАХ ПРОФЕСІЙНОГО \\ СТАНДАРТУ
}

\author{
Larysa ZHURAVLOVA, \\ Лариса ЖУРАВЛЬОВА, \\ Candidate of Pedagogical Sciences, кандидат педагогічних наук, доцент \\ Associate Professor \\ https://orcid.org/0000-0002-4007-1140 \\ zuravlovalarisa@gmail.com \\ Melitopol State Pedagogical \\ University named after Bogdan \\ Khmelnitsky, \\ $\triangle 20$, Getmanska Str. \\ Мелітопольський державний \\ педагогічний університет імені \\ Богдана Хмельницького \\ $\triangle$ вул. Гетьманська, 20 \\ 72312, Melitopol, Zaporizhzhia region \\ 72312, м. Мелітополь, Запорізька \\ область \\ Original manuscript received: October 16, 2019 \\ Revised manuscript accepted: December 11, 2019
}

\begin{abstract}
The article presents of the professional competences of primary school teachers, outlined in the professional standard the "Primary school teacher of the institution of secondary comprehensive education", have been analyzed. It is found out that teachers have the important task of improving their professional skills and expanding their basic professional responsibilities in order to work effectively with children with special educational needs (SENs). This, in turn, requires the expansion and acquisition of logospecific knowledge (LSK) and skills (LSSs) in the field of pedagogical diagnostics, training, upbringing, as well as corrective-developmental and social-pedagogical activities with pupils with impaired speech development, in particular, dysgraphia. The author defines logospecific knowledge and skills that envisage the preparation of primary school teachers to assist pupils with impaired writing skills and taking into account the personal development of children, their needs, age and individual characteristics in their unity. It is noted that the success of a child with difficulty in writing skills or his/her impairment depends in particular on the competence of primary school teachers, their desire to understand the problem, the ability to provide corrective and pedagogical assistance. In the context of the general education space, the issues outlined are of particular importance and determine the need for forming logocompetence of teachers, which involves the acquisition of logospecific knowledge (LSK) and skills (LSSs). It is emphasized that the modern requirements for the education of primary school pupils can be realized if the primary school teacher will be a highly-professional, competent specialist in this field, be aware of the goals and values of this work, be professionally mobile, be able to
\end{abstract}


respond to changes in the social and personal development and psychophysiological features of the child, master new pedagogical technologies.

Key words: logocompetence, primary school teachers, primary schoolchildren, dysgraphia, impairment of writing.

Вступ. Актуальність проблеми формування логопедичної компетентності вчителів початкових класів зумовлена необхідністю організації ефективного корекційно-педагогічного процесу в загальноосвітніх закладах і нормативними документами (Концепція "Нова українська школа" (2017), Положення “Про інклюзивно-ресурсний центр” (2017), Законом України “Про освіту” (2018)), що містять особливі вимоги до вчителів загалом і початкової школи зокрема.

Вітчизняна система освіти спрямована насамперед, на вдосконалення педагогічних процесів у школі іпотребує, відповідно, кваліфікованих учителів, здатних комплексно виконувати професійні завдання, розв'язувати нагальні проблеми та взаємодіяти між собою. У цьому контексті набуває вагомості інклюзивна освіта, яка сьогодні стає невіддільним складником загального педагогічного процесу і спрямовується на розвиток кожної дитини, відповідно до їі особистісних характеристик i особливостей, забезпечуючи розвиток ії розумових і фізичних здібностей іпотенціалу в усіх сфрерах. Досвід європейських країн і вітчизняна педагогічна практика доводять, що здебільшого діти, які потребують соціальної адаптації, корекційно-реабілітаційної допомоги, можуть навчатися в загальноосвітніх школах за моделлю інклюзивної освіти. її використання передбачає надання якісних освітніх послуг дітям з особливими освітніми потребами в звичайних класах загальноосвітніх навчальних закладів за умови відповідної підготовки вчителів та надання підтримки сім'ям (Журавльова, 2014: 108-111). 3 огляду на це, виникає необхідність теоретичної і практичної підготовки вчителів початкових класів для роботи 3 учнями, що мають особливі освітні потреби, серед яких - діти з різними порушеннями усного і писемного мовлення, зокрема з дисграфрією.

Аналіз досліджень і публікацій. Питання професійної компетентності педагогів порушені в роботах В. Баркасі, Л. Васильченко, С. Гончаренка, О. Дубасенюк, С. Демченко, М. Елькіна, В. Калініна, Н. Лісової, О. Митника, Н. Ничкало, Н. Петрікової, О. Савченко, В. Семиченко, Л. Сундєєвої, Л. Тишкової, Т. Ціпан та інших. Так, Н. Петрікова (Петрікова, 2013), Т. Ціпан (Ціпан, 2016: 174-181), зауважують, що професійно-педагогічну компетентність розглядають у контексті проблеми реалізації особистісних характеристик учителя, розвитку його професійної свідомості та рефлексії, динаміки професійного самовизначення. Проте на часі - проблема набуття вчителями початкових класів професійних умінь, пов'язаних із плануванням і реалізацією корекційної складової освітнього процесу. Як твердить Е. Уодлінгтон (E. Wadlington, 2005), нинішні педагоги мають помилкові уявлення про дислексію та недостатньо обізнані 3 цим порушенням. Дослідивши наукові праці, що містять аналіз знань учителів з цього питання, М. Соріано-Феррер та Ж. А. Ечегарай-Бенгоа (Soriano- 
Ferrer, Echegaray-Bengoa, 2014: 203-208) згрупували їх за двома основними напрямами. Праці першого, найбільш поширеного напряму (E. Binks-Cantrell et al., 2012, M. Bos et al., 2001, A. Chesman et al., 2009, R. Joshi et al., 2009, L. Moats and R. Foorman, 2003, S. Piasta et al., 2009, L. Spear-Swerling, 2007, L. Spear-Swerling et al., 2005, E. Washburn et al., 2011) свідчать про те, що і майбутні вчителі, і вчителі з професійним досвідом мають прогалини в знаннях щодо різних лінгвістичних конструкцій, покладених в основу оволодіння дітьми писемним мовленням, зокрема тих, що мають труднощі в навчанні. Праці другого напряму (R. Allington, 1982, S. Bell et al., 2011, E. Washburn et al., 2011, E. Wadlington and P. Wadlington, 2005, E. Washburn et al., 2014), що містять аналіз переконань і поглядів учителів на проблему дислексії, доводять, що досвідчені педагоги мають деякі правильні знання про це порушення, однак у них наявні і певні помилкові уявлення.

Отже, як переконуємось, проблема формування логокомпетентності вчителів початкових класів у процесі підготовки їх до роботи 3 молодшими школярами із дисграфрією в умовах загальноосвітньої школи залишається на сьогодні однією з нагальних і важливих, особливо, 3 огляду на участь сучасних педагогів у різнопрофільній команді, яка здійснює корекційно-розвивальну роботу 3 учнями, що мають порушення мовленнєвого розвитку.

Метою статті є обґрунтування розроблених в аспекті трудових функцій логокомпетентностей учителів початкових класів i характеристика їх у межах професійного стандарту.

Виклад основного матеріалу. У нормативних законодавчих документах останніх років (Закон України “Про освіту", Концепція "Нової української школи") підкреслюється необхідність набуття учнями початкової школи ключових компетенцій. Зокрема, у Концепції "Нова українська школа" наголошується на тому, що однією з ключових компетенцій, яку має набути учень, $€$ вмінням "усно і письмово висловлювати думки, почуття й факти та тлумачити поняття та погляди (через слухання, говоріння, читання, письмо, застосування мультимедійних засобів) ..."(Нова українська школа: порадник для вчителя, 2017: 14). Водночас у документах не приділено належної уваги формуванню в загальноосвітніх навчальних закладах компетенцій з розвитку мовленнєвих навичок у молодших школярів, які мають складні мовленнєві порушення, зокрема дисграфрію. Труднощі формування навичок письма або їх порушення, що виникають у молодших школярів, зазвичай, перешкоджають оволодінню дітьми писемним мовленням як своєрідним засобом спілкування й узагальнення досвіду, засвоєння якого пов'язано з якісними змінами інтелектуальної, емоційної, вольової та інших сфер особистості учнів.

Зауважимо, що сучасному вчителеві початкових класів усе частіше доводиться працювати з дітьми молодшого шкільного віку, які мають специфічні труднощі навчання. 3 огляду на це, вкрай необхідною стає організація логокорекційної допомоги цим учням в умовах загальноосвітньої школи, що передбачає підготовку вчителів початкових 
класів як таких, що активно здійснюють психолого-педагогічний супровід означеної категорії дітей.

Як переконуємось, формування логокомпетентності вчителів початкових класів зумовлено соціальною потребою надання необхідної специфічної освітньої допомоги (НСОД) учням в умовах загальноосвітніх навчальних закладів, що, зі свого боку, дасть змогу вдосконалити корекційно-педагогічний процес і вивести його на якісно новий рівень. Виходячи з пріоритетних напрямів Концепції "Нова українська школа", що передбачають реформування початкової освіти, удосконалення форм, методів і засобів навчання рідної мови учнів початкових класів, орієнтацію стратегічних планів масової школи на інклюзивну освіту з розширенням інклюзивних практик, наголосимо на необхідності підвищення кваліфрікації вчителів початкових класів, зокрема на підготовці їх до роботи з учнями, що мають труднощі формування навичок письма або його порушення в процесі оволодіння писемним мовленням.

Як показує практика, учитель початкових класів сьогодні стикається з низкою проблем, до яких він виявляється не готовим унаслідок змісту своєї професійної підготовки. Корекційно-педагогічна робота з дітьми молодшого шкільного віку з порушеннями мовленнєвого розвитку, зокрема з дисграфією, повинна мати міждисциплінарне підґрунтя й базуватися на психологічних, соціальних, фізіологічних і педагогічних знаннях про цю категорію школярів.

Один зі шляхів розв'язання окресленої нами проблеми вбачаємо в розробленні системи роботи, спрямованої на формування логокомпетентності вчителів початкових класів.

Аналіз професійних компетентностей учителя початкових класів, що наведені в професійному стандарті "Вчитель початкових класів закладу загальної середньої освіти" (Професійний стандарт, 2018), свідчить про те, що перед учителями постає важливе завдання підвищення рівня професійної майстерності та розширення своїх основних професійних обов'язків для здійснення ефективної роботи з дітьми, що мають особливі освітні потреби. Це, зі свого боку, потребує здобуття й розширення логоспецифічних знань (ЛСЗ) і логоспецифічних умінь (ЛСУ) у сфері педагогічної діагностики, навчанні, вихованні, а також у корекційно-розвивальній і соціально-педагогічній діяльності з учнями, що мають порушення мовленнєвого розвитку, зокрема дисграфрію.

Згідно з завданням дослідження ми визначили логокомпетентності і вміння, якими мають оволодіти вчителі початкових класів для надання допомоги учням з порушенням мовленнєвого розвитку та труднощами формування навичок письма, ураховуючи особливості особистісного розвитку таких дітей, їхні потреби, вікові та індивідуальні характеристики.

Під логокомпетентністю вчителя початкових класів ми розуміємо здатність здійснювати корекційно-педагогічну роботу з дітьми, які мають труднощі формування навичок письма або/та його порушення різної етіології в умовах загальноосвітнього простору. Сучасні вимоги до освіти молодших школярів можуть бути реалізовані, якщо вчитель початкової 
Серія: Педагогічні науки. - Вип.3. - Бердянськ : БДПУ, 2019. - 453 с.

школи буде високопрофесійним, компетентним фахівцем у своїй галузі, матиме фундаментальну освітню підготовку й володітиме логоспецифічними знаннями (ЛСЗ) й уміннями (ЛСУ). Такий спеціаліст, крім того, повинен усвідомлювати цілі й значення своєї професійної діяльності, бути професійно мобільним, здатним до інноваційної роботи, самовдосконалення, професійної активності, спроможним глибоко мислити і відчувати, гнучко реагувати на специфічні особливості дитини, моделювати освітньо-виховний процес з урахуванням індивідуальних особливостей учнів, самостійно розробляти і втілювати в практику школи нові ідеї та технології навчання і розвитку.

На підставі проведення комплексної діагностики мовленнєвого розвитку молодших школярів із дисграфією та анкетування вчителів початкових класів щодо їх обізнаності з теоретичними іпрактичними питаннями навчання учнів з труднощами формування навичок письма або його порушеннями в системі закладів масової загальної середньої освіти, а також спираючись на професійний стандарт (Професійний стандарт, 2018), ми визначили зміст, методи й організаційні форми навчання і підвищення кваліфікації вчителів початкової школи для роботи з означеною категорією дітей. Це допоможе їм сформувати здібності, необхідні для вчасного виявлення труднощів формування навичок письма в молодших школярів у процесі оволодіння ними писемним мовленням, запобігти порушенням письма та імплементувати в корекційно-педагогічну практику методи інтегрально-педагогічної корекційно-розвивальної роботи в умовах загальноосвітнього простору. Професійний стандарт має певну структуру і складається з переліку трудових функцій (з умовними позначеннями), до яких належать професійні компетентності, яким відповідають певні знання, уміння й навички.

Спираючись на професійний стандарт і виділені в ньому трудові фуннції, що охоплюють відповідні трудові дії та операції, професійні компетентності, знання, уміння та навички, нами розроблені логокомпетентності вчителів початкових класів у межах тих профільних компетентностей, що, на наше переконання, потребують уточнення з логопедичної позиції в контексті комплексної роботи з дітьми, які мають труднощі формування навичок письма або його порушення, зокрема дисграфію.

Розроблені логокомпетентності мають умовні позначення відповідно до професійних компетентностей із додаванням логоспецифічних знань (ЛСЗ) і логоспецифічних умінь (ЛСУ).

Розглянемо їх більш детально в контексті трудових функцій, наведених у профресійному стандарті (Професійний стандарт, 2018: 4-29).

Так, в аспекті трудової функції А "Планування і здійснення освітнього процесу" ми виокремили логокомпетентності в межах професійних компетентностей А4, А5, А6, які передбачають низку професійних знань і умінь:

Профресійні компетентності:

- А4. Здатність до організації взаємодії з профрільними фрахівцями 
щодо планування освітнього процесу. Професійно-профільні знання: А431. Завдання та обов'язки профільних фахівців, необхідні для планування та організації застосування засобів педагогічного впливу на учнів та/або учнівський колектив. Професійно-профрільні уміння: А4У1. Співпрацювати та взаємодіяти з профільними фрахівцями щодо планування педагогічного впливу та/або результатів навчання, виходячи з потреб і можливостей учнів та/або учнівського колективу. Розроблені нами логокомпетентності: А4.Л.1. Здатність використовувати спеціальні знання під час планування та організації спільної міждисциплінарної роботи. Логоспецифічні знання: А4.Л.С.3.1. Розуміння структури роботи з дітьми, що мають труднощі фрормування письма та/або його порушення, для планування та організації спільної роботи міждисциплінарного характеру. Логоспецифічні уміння: А4.Л.С.У.1. Уміти планувати й організовувати роботу в команді, володіючи техніками постановки загальних цілей у спільній роботі.

- A5. Здатність до організації та проведення педагогічної діагностики учня. Професійно-профільні знання: А531. Ознаки, які характеризують стан і результати процесу навчання учнів класу / окремого учня в освітніх галузях, що визначені Державним стандартом початкової освіти. Професійно-профільні уміння: А5У2. Визначати тенденції, динаміку дидактичного процесу. А5УЗ. Прогнозувати можливі відхилення від мети в процесі навчання учнів класу / окремого учня. Розроблені нами логокомпетентності: А5.Л.2. Здатність організовувати та проводити діагностичне обстеження дітей з труднощами формування письма та/або його порушеннями, використовувати спеціальні знання. Логоспецифічні знання: А5.Л.С.3.2. Знання різних форм, інструментальних засобів діагностики та оцінки динаміки прогресу корекційної роботи з молодшими школярами з порушенням письма. Логоспецифічні уміння: А5.Л.С.У.2. Володіння педагогічними засобами розпізнавання порушень письма у молодших школярів в умовах масового загальноосвітнього середовища, визначати динаміку подальшої корекційної роботи.

- А6. Здатність до здійснення освітнього процесу. Професійнопрофільні знання: А631. Теоретичні основи процесу навчання учнів початкової школи. Професійно-профрільні уміння: А6УЗ. Коригувати власну діяльність, виходячи з конкретної навчальної ситуації. А6У4. Ураховувати індивідуальні особливості та потреби учнів упроцесі організації освітньої діяльності. А6У5. Здійснювати процес навчання учнів відповідно до психолого-педагогічних закономірностей формування умінь і навичок, розвитку пізнавальних потреб і можливостей учнів. Розроблені нами логокомпетентності: А6.Л.3. Здатність організовувати та здійснювати навчальну, корекційну, розвивальну та профрілактичну роботу з учнями, що мають труднощі формування та/або порушення письма, з урахуванням його структури, вікових та індивідуальних особливостей дітей, організовуючи спеціальне середовище і створюючи необхідні умови. Логоспецифічні знання: А6.Л.3.3. Теоретичні основи 
Серія: Педагогічні науки. - Вип.3. - Бердянськ : БДПУ, 2019. - 453 с.

специфіки застосування різних педагогічних методів і технік навчання письма дітей з порушеннями усного і писемного мовлення. Логоспецифічні уміння: А6.Л.С.У.3. Уміння адаптувати план занять та коригувати власну діяльність відповідно до індивідуальних особливостей і потреб учнів з труднощами формування та/або порушенням письма в умовах загальноосвітнього середовища.

В аспекті трудової функції Б “Забезпечення і підтримка навчання, виховання і розвитку учнів в освітньому середовищі та родині” ми виокремили логокомпетентності в межах професійних компетентностей Б3, Б5, Б6, Б7, Б8, Б9, які передбачають низку професійних знань і умінь:

\section{Професійні компетентності:}

- Б3. Здатність до використання в освітньому процесі системи теоретичних знань з освітніх галузей, визначених Державним стандартом початкової освіти. Професійно-профільні знання Б331. Система теоретичних знань з освітніх галузей, визначених Державним стандартом початкової освіти. Професійно-профільні уміння: БЗУЗ. Прогнозувати можливі помилки учнів, виходячи з систем теоретичних знань освітніх галузей, визначених Державним стандартом початкової освіти. Розроблені нами логокомпетентності: БЗ.Л.4. Здатність до використання в освітньому процесі системи теоретичних знань, що пов'язані з розумінням структури писемного мовлення та його розвитку. Логоспецифічні знання: Б3.Л.С.4.1. Розуміння письма як мовного процесу, що має лінгвістичне та психолінгвістичне підґрунтя, а також розуміння письма як виду діяльності, що дає змогу формувати його як навичку. Б3.Л.С.3.4.2. Розуміння основ нейропсихологічних механізмів формування навичок письма; знання вчителя в галузі психолінгвістики. Б3.Л.С.3.4.3. Розуміння динаміки розвитку писемного мовлення. Логоспецифічні уміння: Б3.Л.С.У.4.1. Уміти диференціювати поняття “письмо" та “писемне мовлення". Б3.Л.С.У.4.2. Уміти бути пильним, відрізняти вияви порушень базових навичок письма від еволюційних помилок (тобто помилок, що виникають у процесі навчання письма). Б3.Л.С.У.4.3. Уміти організовувати педагогічні умови з урахуванням спеціальних потреб кожної дитини в процесі формування письма, відповідно до її потенційних можливостей та особистісних характеристик.

- Б5. Здатність до проведення формувального та підсумкового оцінювання навчальних досягнень учнів. Професійно-профільні знання А532. Засоби контролю, перевірки й оцінювання (формувального та підсумкового), збір та узагальнення статистичних даних та їх аналіз. Професійно-профільні уміння: Б5У2. Складати завдання для комбінованих контрольних робіт або тести для перевірки навчальних досягнень учнів з освітніх галузей, визначених Державним стандартом початкової освіти. Розроблені нами логокомпетентності: Б5.Л.5. Здатність використовувати спеціальні знання під час проведення формувального та підсумкового оцінювання навчання учнів з труднощами формування письма та/або його порушеннями. 
Логоспецифічні знання: Б5.Л.С.3.5.1. Ознайомлення з базовими питаннями нейропсихології та психолінгвістики для розуміння основних механізмів порушень формування навичок письма. Б5.Л.С.3.5.2. Розуміння динаміки розвитку писемного мовлення та його порушень. Логоспецифічні уміння: Б5.Л.С.У.5 Уміння проводити спостережну діагностику та стежити за процесом мовленнєвого розвитку під час корекційної роботи.

- Б6. Здатність до відстеження динаміки та забезпечення підтримки особистісного розвитку дитини в освітньому процесі. Професійно-профрільні знання: Б631. Вікові особливості динаміки становлення пізнавальних процесів учнів. Б632. Індивідуальні особливості динаміки становлення пізнавальних процесів учнів. Б633. Особливості розвитку особистості учня початкової школи. Професійнопрофільні уміння: Б6У1. Ураховувати вікові особливості учнів під час добору змісту, методів, засобів і форм навчання в освітніх галузях, визначених Державним стандартом початкової освіти. Б6У2. Ураховувати вікові особливості учнів у процесі організації навчальної взаємодії та зворотного зв'язку. Б6УЗ. Ураховувати індивідуальні особливості учнів під час добору змісту, методів, засобів і форм навчання в освітніх галузях, визначених Державним стандартом початкової освіти. Б6У4. Ураховувати індивідуальні особливості учнів у процесі організації навчальної взаємодії та зворотного зв'язку. Б6У5. Ураховувати особливості розвитку особистості учня під час проєктування та застосування методів педагогічного впливу. Розроблені нами логокомпетентності: Б6.Л.6. Здатність до відстеження динаміки та забезпечення психологопедагогічного супроводу учнів початкових класів з труднощами формування та/або порушеннями письма. Логоспецифічні знання: Б6.Л.С.3.6.1. Знання характеристик порушень писемного мовлення, а також письма як початкового ступеня в процесі оволодіння писемним мовленням. Б6.Л.3.6.2. Знання специфріки застосування різних педагогічних методів і технік навчання письма дітей з порушеннями усного і писемного мовлення. Логоспецифічні уміння: Б6.Л.С.У.6.1. Уміння застосовувати педагогічні засоби навчання письма молодших школярів відповідно до індивідуально-психологічних особливостей дітей і групи. Б6.Л.С.У.6.2. Уміння застосовувати різні педагогічні техніки первинної допомоги та навчання письма з урахуванням виду порушення та індивідуальних особливостей учнів. Б6.Л.С.6.У.6.3. Уміти організовувати пропедевтичну діяльність із запобігання порушенням письма в межах навчального процесу. Б6.Л.С.У.6.4. Спостерігати за динамікою прогресу корекційної роботи.

- Б7. Здатність до надання батькам (особам, що їх замінюють) порад і рекомендацій щодо підтримки навчальної діяльності учня за межами закладу освіти. Професійно-профільні знання: Б733. Особливості комунікації з батьками (особами, що їх замінюють). Професійно-профільні уміння: Б7У4. Давати батькам чіткі та зрозумілі поради та рекомендації щодо підтримки навчальної діяльності учнів за 
Серія: Педагогічні науки. - Вип.3. - Бердянськ : БДПУ, 2019. - 453 с.

межами закладу освіти. Б7У5. Використовувати різноманітні засоби для налагодження ефективної комунікації з батьками (особами, які їх замінюють), зокрема й інтернет-ресурси (спеціально створені сайти, соціальні мережі тощо). Розроблені нами логокомпетентності: Б7.Л.7. Здатність використовувати логоспецифічні знання для надання допомоги батькам учнів з труднощами формування письма та/або його порушеннями в процесі їх роботи в домашніх умовах. Логоспецифічні знання: Б7.Л.С.3.7. Знання форм роботи з батьками дітей, які мають труднощі формування письма та/або його порушення. Логоспецифічні уміння: Б7.Л.С.У.7. Уміти сприяти розвитку навичок і вмінь батьків допомагати в домашніх умовах своїм дітям з труднощами формування письма та/або його порушеннями.

- Б8. Здатність до організації взаємодії з батьками в різних формах. Професійно-профільні знання: Б732. Функції та основні форми роботи з батьками (особами, що їх замінюють). Професійнопрофільні уміння: Б8У1. Ознайомлювати батьків зі змістом та особливостями освітнього процесу, що організовується закладом освіти. Б8У3. Забезпечувати педагогічний супровід виховання дитини в родині. Розроблені нами логокомпетентності: Б8.Л.8. Здатність використовувати логоспецифічні знання для організації різних форм спільної роботи з батьками учнів, що мають труднощі формування та/або порушення письма. Логоспецифічні знання: Б7.Л.С.З.8. Знання форм роботи з батьками дітей з труднощами формування письма та/або його порушеннями. Логоспецифічні уміння: Б7.Л.С.У.8. Уміти сприяти розвитку навичок і вмінь батьків допомагати в домашніх умовах своїм дітям з труднощами формування письма та/або його порушеннями.

- Б9. Здатність до координації взаємодії із зацікавленими особами для гармонійного розвитку учнів. Професійно-профільні знання: Б931. Повноваження вчителя щодо залучення зацікавлених осіб для гармонійного розвитку учнів. Професійно-профільні уміння: Б9У1. Організовувати взаємодію з профільними фахівцями для забезпечення гармонійного розвитку учнів. Розроблені нами логокомпетентності: Б9.Л.9. Здатність до взаємоузгодженої діяльності в міждисциплінарній команді в процесі здійснення корекційно-розвивальної роботи з дітьми, що мають труднощі формування письма та/або його порушення. Логоспецифічні знання: Б9.Л.С.3.9. Розуміння свої повноважень у межах роботи з дітьми з труднощами формування письма та/або його порушеннями. Логоспецифічні уміння: Б9.Л.С. У.9. Уміти працювати в умовах взаємозв'язку з різнопрофільними фахівцями, спрямовуючи свою роботу на спільні корекційно-розвивальні цілі.

В аспекті трудової функції В “Створення освітнього середовища” ми виокремили логокомпетентності в межах професійних компетентностей B1, В3, В5, які передбачають низку професійних знань і умінь:

Профресійні компетентності:

- В1. Здатність до створення безпечних і психологічно комфортних умов освітнього процесу. Професійно-профільні знання: В132. Ознаки 
психологічно комфортних умов освітнього процесу. Професійнопрофільні уміння: В1У2. Забезпечувати / створювати психологічно комфортні умови освітнього процесу. Розроблені нами логокомпетентності: В1.Л.10. Здатність використовувати спеціальні знання для забезпечення в загальноосвітньому закладі психологічно здорового клімату в процесі навчання молодших школярів з труднощами формування та/або порушенням письма та створення спеціальних умов для корекційно-розвивальної роботи. Логоспецифічні знання: В1.Л.С.3.10. Психологічні характеристики дітей молодшого шкільного віку з порушенням мовленнєвого розвитку. Логоспецифічні уміння: В1.Л.С.У.10. Забезпечувати / створювати психологічно комфортні умови навчального процесу відповідно до особистісних характеристик дитини з труднощами формування та/або порушенням письма.

- В3. Здатність до змістового наповнення освітнього середовища відповідно до вимог Державного стандарту початкової освіти. Професійно-профільні знання: В331. Вимоги до змістового наповнення освітнього середовища. Професійно-профільні уміння: В3У2. Добирати й застосовувати дидактичні матеріали та засоби для уроків та інших організаційних форм навчання, для оформлення класної кімнати. Розроблені нами логокомпетентності: В3.Л.11. Здатність до змістового наповнення освітнього середовища відповідно до вимог логокорекційної роботи. Логоспецифічні знання: В3.Л.С.3.11. Ознайомлення з різним дидактичним матеріалом для корекційнорозвивальної роботи в освітньому середовищі. Логоспецифічні уміння: В3.Л.С.У.11. Уміння добирати й застосовувати дидактичні матеріали та засоби для корекційно-розвивальної роботи з учнями початкових класів з труднощами формування та/або порушення письма в умовах закладу масової загальної середньої освіти.

- В5. Здатність до врахування в процесі створення освітнього середовища індивідуальних потреб учнів, зокрема й обдарованих дітей, дітей, які мають особливі освітні потреби. Професійно-профільні знання (згідно зі стандартом, використовуються знання 3 трудової функції Б): Б632. Індивідуальні особливості динаміки становлення пізнавальних процесів учнів. Б633. Особливості розвитку особистості учня початкової школи. В531. Індивідуальні потреби учнів у пізнавальній сфері, у сфері особистісного та фрізичного розвитку. Професійнопрофрільні уміння (згідно зі стандартом, використовуються уміння з трудової функції Б): Б6УЗ. Ураховувати індивідуальні особливості учнів під час добору змісту, методів, засобів і форм навчання в освітніх галузях, визначених Державним стандартом початкової освіти. Б6У4. Ураховувати індивідуальні особливості учнів у процесі організації навчальної взаємодії та зворотного зв'язку. Б6У5. Ураховувати особливості розвитку особистості учня під час проєктування та застосування методів педагогічного впливу. В5У1. Ураховувати індивідуальні пізнавальні потреби та інтереси учнів під час формування освітнього середовища. Розроблені нами логокомпетентності: 
Серія: Педагогічні науки. - Вип.3. - Бердянськ : БДПУ, 2019. - 453 с.

В5.Л.12. Здатність до врахування під час створення освітнього середовища індивідуальних потреб учнів початкових класів з труднощами формування та/або порушеннями письма. Логоспецифічні знання: В5.Л.С.3.12. Індивідуальні особливості динаміки психомовленнєвого розвитку у дітей молодшого шкільного віку з труднощами формування та/або порушеннями письма. Логоспеціфічні уміння: В5.Л.С.У.12. Уміння визначати зміст і добирати методи, засоби та форми корекційно-розвивальної роботи з урахуванням індивідуальних особливостей учнів, що мають труднощі формування та/або порушення письма, та їхніх інтересів.

В аспекті трудової фрункції Г “Рефрлексія та професійний саморозвиток"

ми виокремили логокомпетентності в межах професійних компетентностей Г1, ГЗ, Г5, які передбачають низку професійних знань і умінь:

Професійні компетентності:

- Г1. Здатність до усвідомлення своєї ролі як педагога початкової освіти, а також системи цінностей, мети і завдань професійної діяльності вчителя. Професійно-профрільні знання: Г132. Ціннісні орієнтації вчителя початкових класів закладу загальної середньої освіти. Професійно-профрільні уміння: Г1УЗ. Поважати особистість дитини й толерантно ставитися до неї. Толерантно ставитися до дітей з особливими потребами та підтримувати їх. Демонструвати повагу до особистості дитини й толерантне ставлення до неї, зокрема й до дитини з особливими потребами. Розроблені нами логокомпетентності: Г1.Л.13. Здатність до усвідомлення своєї ролі як паритетного учасника міждисциплінарної команди в корекційно-педагогічному процесі, який має мотив і бажання здійснювати корекційно-розвивальну роботу з дітьми, що мають труднощі формування та/або порушення письма. Логоспецифічні знання: Г1.Л.С.3.13. Ціннісні орієнтації вчителя початкових класів у контексті роботи з молодшими школярами з труднощами формування письма та/або його порушеннями в умовах закладу масової загальної середньої освіти. Логоспецифічні уміння: Г1.Л.С.У.13. Ставитися толерантно до всіх учасників корекційно-педагогічного процесу (особистості дитини з порушенням письма, її батьків, різнопрофрільних фрахівців, зокрема й до себе), поважати їх.

- ГЗ. Здатність до визначення сильних і слабких сторін власної педагогічної діяльності. Професійно-профрільні знання: ГЗ31. Професійно значущі особистісні якості педагога (рефлексія, гнучкість, емпатія, відкритість, товариськість, емоційна привабливість). Професійно-профрільні уміння: ГЗУ1. Передбачати можливі реакції учнів на певні педагогічні впливи; відчувати їхній емоційний стан. ГЗУ2. Виявляти гнучкість під час вибору методів педагогічного впливу з урахуванням індивідуальних особливостей учнів. Розроблені нами логокомпетентності: ГЗ.Л.14. Здатність до оцінки власної діяльності як учасника міждисциплінарної команди в корекційно-педагогічному процесі. Логоспецифічні знання: ГЗ.Л.С.3.14. Професійно значущі 
особистісні якості педагога, що необхідні для роботи з учнями початкових класів з порушенням письма в умовах закладу масової загальної середньої освіти, а саме: чуйність, пильність, ресрлексія, гнучкість, емпатія, відкритість, комунікабельність, емоційна привабливість. Логоспецифічні уміння: ГЗ.Л.С.У.14.1. Виявляти гнучкість під час вибору методів, технік і добору дидактичного матеріалу в процесі корекційно-педагогічної роботи з дітьми, що мають порушення письма, ураховуючи їхні індивідуальні потреби, інтереси та особливості розвитку. ГЗ.Л.С.У.14.2. Передбачати можливі реакції учнів з порушенням письма на труднощі, що виникають під час навчання. ГЗ.Л.С.У.14.3. Уміння визначати сильні та слабкі сторони своєї роботи з учнями початкових класів, що мають порушення письма, бути чуйним і тонко відчувати їхні реакції на труднощі.

- Г5. Здатність до усвідомлення потреби в саморозвитку для набуття додаткових професійних компетентностей. Професійнопрофільні знання: Г531. Професійні компетентності вчителя початкових класів закладу загальної середньої освіти. Професійно-профрільні уміння: Г5У1. Аналізувати й оцінювати власний рівень професійних компетентностей. Г5У2. Визначати власні потреби в розвитку професійних компетентностей. Розроблені нами логокомпетентності: Г5.Л.15. Здатність до усвідомлення потреби в саморозвитку для підвищення рівня логоспецифічних знані і вмінь, необхідних для роботи з учнями з порушеннями письма. Логоспецифічні знання: Г5.Л.С.3.15. Логокомпетентність учителя початкових класів закладу масової загальної середньої освіти. Логоспецифічні уміння: Г5.Л.С.У.15. Наявність інтересу та вияв бажання до покращення власних логоспецифічних знань, умінь: читання спеціальної літератури, пошук комп'ютерних спеціальних корекційно-освітніх програм, відвідування семінарів, майстер-класів, обговорення різних проблемних ситуацій, що виникають у роботі з дітьми, які мають труднощі формування письма та/або його порушення, позитивне сприйняття і прийняття порад фахівців використання їх надалі у своїй практиці.

Висновок. Отже, успіх дитини з труднощами формування навичок письма та/або його порушеннями залежить, зокрема, від компетентності вчителя початкових класів, від його бажання розібратися в проблемі, від уміння надавати корекційно-педагогічну допомогу. В умовах загальноосвітнього простору ці питання набувають особливого значення й зумовлюють необхідність формування логокомпетентності вчителів, а саме: здобуття ними логоспецифічних знань (ЛСЗ) і набуття логоспецифічних умінь (ЛСУ).

\section{Література}

1.Журавльова Л. С. Аналіз зарубіжного досвіду з проблеми організації та змісту інклюзивної освіти / Л. С. Журавльова // Науковий часопис НПУ імені М.П. Драгоманова. Серія 19 "Корекційна педагогіка та психологія". - 2014. Вип. 26. - С. 108-111. — URL: http://enpuir.npu.edu.ua/handle/123456789/7694. 
2.Закон України “Про освіту” від 05 вересня 2017 року (зі змінами, чинними від 19.01.2019). — URL: https://www.pedrada.com.ua/files/articles/ 1484/ Zakon_Pro_osvitu_2019_Pedrada.pdf.

3.Нова українська школа: порадник для вчителя / Під заг. ред. Бібік Н. М. К.: ТОВ «Видавничий дім «Плеяди», 2017. — 206 с.

4.Петрікова Н. І. Професійна компетентність учителя - важлива складова

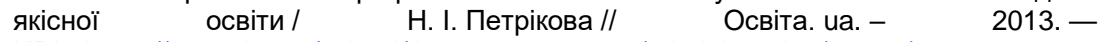
URL: https://ru.osvita.ua/school/ lessons summary/administration/34011/.

5.Положення про інклюзивно-ресурсний центр від 12 липня 2017 року. URL: http://old.mon.gov.ua/ua/about-ministry/normative/7892.

6.Професійний стандарт "Вчитель початкових класів закладу загальної середньої освіти". Наказ Міністерства соціальної політики України про затвердження професійного стандарту "Вчитель початкових класів закладу загальної середньої освіти” № 1143 від 10.08.2018 р. - URL: https:// zakon.rada.gov.ua/rada/show/v1143732-18.

7.Ціпан Т. С. Професійна компетентність сучасного вчителя / Т. С. Ціпан // Інноватика у вихованні. - 2016. - Вип. 3. - С.174-181. - URL: http://nbuv.gov.ua/UJRN/ inuv 2016322.

8.Soriano-Ferrer M., Echegaray-Bengoa J. A. A Scale of Knowledge and Beliefs about Developmental Dyslexia: Scale Development and Validation / M. SorianoFerrer, J. A. Echegaray-Bengoa // Procedia - Social and Behavioral Sciences. 2014. - Vol. 132. - P. 203-208. — DOI: 10.1016/j.sbspro.2014.04.299.

\section{References}

1. Zhuravlova, L. S. (2014). Analiz zarubizhnoho dosvidu z problemy orhanizatsii ta zmistu inkliuzyvnoi osvity. Naukovyi chasopys NPU imeni M. P. Drahomanova. Seriia 19 "Korektsiina pedahohika ta psykholohiia". Vyp. 26. S. 108-111. Rezhym dostupu: http://enpuir.npu.edu.ua/handle/123456789/7694 [in Ukrainian].

2. Zakon Ukrainy (2017) "Pro osvitu" vid 05 veresnia 2017 roku (zi zminamy, chynnymy vid 19.01.2019): [Elektronnyi resurs]. - Rezhym dostupu: https://www.pedrada.com.ua/files/articles/1484/Zakon_Pro_osvitu_2019_Pedrada.pdf [in Ukrainian].

3. Nova ukrainska shkola: poradnyk dlia vchytelia (2017) [New Ukrainian School: Teacher Advisor]. Pid zah. red. Bibik N. M. K.: TOV «Vydavnychyi dim «Pleiady», 206. [in Ukrainian].

4. Petrikova N. I. (2013) Profesiina kompetentnist uchytelia - vazhlyva skladova yakisnoi osvity [Elektronnyi resurs] / N. I. Petrikova // Osvita.ua. Rezhym dostupu: https://ru.osvita.ua/school/lessons summary/administration/34011/ [in Ukrainian].

5. Polozhennia pro inkliuzyvno-resursnyi tsentr (2017): [Elektronnyi resurs]. Rezhym dostupu : http://old.mon.gov.ua/ua/about-ministry/normative/7892 [in Ukrainian].

6. Profesiinyi standarti (2018) "Vchytel pochatkovykh klasiv zakladu zahalnoi serednoi osvity". Nakaz Ministerstva sotsialnoi polityky Ukrainy pro zatverdzhennia profesiinoho standartu "Vchytel pochatkovykh klasiv zakladu zahalnoi serednoi osvity" № 1143, vid 10.08.2018r. Rezhym dostupu:https://zakon.rada.gov.ua/rada/show/v1143732-18 [in Ukrainian].

7. Tsipan T.C., (2016) Profesiina kompetentnist suchasnoho vchytelia. Innovatyka u vykhovanni. 3. 174-181. Rezhym dostupu: http://nbuv.gov.ua/UJRN/inuv 2016322 [in Ukrainian].

8. Soriano-Ferrer, M., \& Echegaray-Bengoa, J. A. (2014). A Scale of Knowledge and Beliefs about Developmental Dyslexia: Scale Development and Validation. Procedia - Social and Behavioral Sciences, 132, 203-208. DOI: 10.1016/j.sbspro.2014.04.299 [in English]. 


\begin{abstract}
АНОТАЦИЯ
У статті обгрунтовано необхідність розроблення в аспекті трудових фрункцій логокомпетентностей учителів початкових класів і схарактеризовано їх у межах професійного стандарту "Вчитель початкових класів закладу загальної середньої освіти". Зазначено, що актуальність такої розробки зумовлена завданням підвищення якості корекційно-педагогічного процесу в загальноосвітніх закладах. Наголошено, що система освіти передбачає вдосконалення педагогічних процесів ушколі іпотребує кваліфікованих учителів, здатних системно виконувати професійні завдання, розв'язувати першочергові проблеми й взаємодіяти між собою. Підкреслено, що сучасному вчителеві початкових класів усе частіше доводиться стикатися зі специфічним труднощами в навчанні дітей молодшого шкільного віку з особливими освітніми потребами (ООП). Саме тому необхідним є процес організації логокорекційної допомоги цим дітям в умовах загальноосвітньої школи, який передбачає підготовку вчителів початкових класів як активних учасників багатопрофрільної команди, що здійснює психолого-педагогічний супровід означеної категорії дітей. З огляду наче, проблема фрормування логокомпетентності вчителів початкових класів у процесі підготовки їх до роботи з молодшими школярами з дисграфрією в умовах загальноосвітньої школи є на сьогодні однією з нагальних івагомих. У контексті цієї проблеми перед учителями постає важливе завдання- підвищити рівень професійної майстерності й розширити свої основні профессійні обов'язки для здійснення ефективної роботи з дітьми з особливими освітніми потребами. Це, зі свого боку, потребує здобуття вчителями логоспецифрічних знань (ЛСЗ) і набуття логоспецифрічних умінь (ЛСУ) у сфрері педагогічної діагностики, навчанні, вихованні, а також у корекційнорозвивальній і соціально-педагогічній діяльності з учнями, що мають порушення мовленнєвого розвитку, зокрема дисграфрію. З огляду на це, сучасні вимоги до освіти молодших школярів можуть бути реалізовані лише за умови, коли вчитель початкової школи буде високопрофресійним, компетентним фахівцем у своїй галузі, здатним усвідомлювати цілі й значення своєї роботи, реагувати на зміни в суспільно-особистісному розвитку дитини та їі психофрізіологічних особливостях, опановувати нові педагогічні технології і втілювати їх в освітній прочес початкової школи.
\end{abstract}

Ключові слова: логокомпетентність, учителі початкових класів, молодші школярі, дисграфрія, порушення письма. 